\section{A Farewell to Intertax}

Fred C. de Hosson
The time has come to say farewell to the readers of Intertax.

More than thirty years ago I paid a visit to the late professor Albert Radler, a legendary tax lawyer, in Munich. He had requested me to take over the chief editor ship of the journal. I accepted. He was clearly happy to transfer the responsibility and I soon found out why that was.

In those early years, the late eighties, developments in international tax law were largely confined to new national legislation with a potential impact on international investments and new bilateral tax treaties. It was not easy to solicit sufficient articles in order to fill a monthly journal. I do recall some difficult moments.

Things changed in the nineties thanks to the 1990 direct tax measures of the then European Community and the 'discovery' of the direct application of the nondiscrimination principle in the direct tax area. These major developments resulted in a flood of articles. Even so that it was decided to establish a new specialized journal (EC Tax Review) as a spin-off. However, till this date, Intertax continues to publish important articles on EC law.

In the new century the globalization phenomenon brought a new slew of major international tax issues. To mention a few: the application of the widely accepted transfer pricing rules in a supply chain context; the valuation of the all-important intangible assets, the validity of established source concepts in the internet environment.

In the aftermath of the deep 2007 financial crisis, multilateral efforts to curb (sometimes perceived) tax avoidance and evasion by multinational corporations and wealthy individuals has become a ground swell. 'Fairness' (whatever that concept may mean in legal terms) in the location of profits became de rigueur, acronyms like 'BEPS' household names. This issue of the journal too bears witness to the importance of these developments.
All this resulted in a flood of articles for our journal. Obviously a chief- editor is a happy man when he receives plenty of articles. At the same time, the journal has limited space so it has become increasingly necessary to be selective. The first step in this process has been to move from a system relying on an extensive network of country correspondents to a small editorial board of wellestablished academics. Until a few years ago, a major role in the Board was played by professor Pasquale Pistone who introduced the concept of 'double blind' peer review for selected articles. Especially for academics, the possibility to have their articles published in the peer-reviewed section of the journal is of the essence.

It is now the time to go further and have all submitted articles subjected to some form of peer review. Only then we can be sure that the journal maintains, or even improves, its standing among the world's leading tax journals.

I am not the man to guide this process in the years to come. As I retired from my firm (Baker \& McKenzie) a few years ago, I am gradually loosing contact with the allimportant practice of international tax law. Besides I am interested in many other things than tax law and therefore not sure I want to dig into the ever more complicated details of legislative and case law developments. In other words, it is time to go.

Fortunately I do not have to worry about my succession. During the last decade I have been supported by an excellent Editorial Board. In day to day management especially professors Ana Paula Dourado and Alexander Rust have been indispensable. I count myself lucky that professor Ana Paula Dourado has been willing to accept the chief-editorship of the journal. A very safe pair of hands indeed. I am sure that Intertax will prosper under her editorship.

I wish you all the best. 